\title{
ARTIGO
}

do/ https://doi.org/10.22481/rpe.v16i43.6841

\section{PHENOMENOLOGY AND THE DEVELOPMENT OF AN INNOVATIVE STYLE FOR MANAGING A MODERN EDUCATIONAL LYCEUM}

\author{
FENOMENOLOGÍA Y EL DESARROLLO DE UN ESTILO DE GESTIÓN INNOVADOR \\ EN LICEO EDUCACIONAL MODERNO
}

\begin{abstract}
FENOMENOLOGIA E O DESENVOLVIMENTO DE UM ESTILO DE GESTÃO INOVADORA DO LYCEUM EDUCACIONAL
\end{abstract}

Andrey I. Shutenko

Belgorod State Technological University named after V.G. Shukhov - Russia

Anastasia V. Koreneva

Murmansk Arctic State University - Russia

Inna V. Ryzhkova

Murmansk Arctic State University - Russia

Larisa P. Morina

St. Petersburg State University - Russia

Alexander V. Apykhtin

St. Petersburg State University - Russia

Galina A. Romanova

Academy of Public Administration, Moscow Region - Russia

Resumo: O objetivo deste artigo é apresentar as características, o conteúdo e a lógica do desenvolvimento de um estilo de gerenciamento inovador entre os diretores de lyceums educacionais da Rússia moderna. O estudo revela as características específicas desse estilo de gestão, que se resumem à capacidade do gerente de promover o espaço educacional do lyceum para o estado de um sistema em desenvolvimento dinâmico que atende aos requisitos modernos de treinamento de especialistas uma economia inovadora. Um critério-chave para um estilo de gerenciamento inovador foi a capacidade do gerente de dar uma contribuição pessoal à promoção da inovação. Esse critério tornou possível identificar os níveis de crescimento do estilo inovador de gerenciar o lyceum (reprodutivo, adaptável, modelagem local, modelagem de sistema, inovação inovadora). Um modelo de atividade gerencial inovadora foi desenvolvido para o chefes do lyceums, que apunta a la formación de un potencial de liderazgo constructivo y un dinámico "auto-concepto" de gestión. É revelada a lógica da formação de um estilo de gestão inovador, que consiste em três estágios: reflexivo, identificação e o estágio da autorrealização profissional. Como resultado da aplicação dessa lógica, os 
gerentes do grupo experimental desenvolveram melhor tolerância e flexibilidade da posição, aumentaram sua criatividade e capacidade de suportar estresse prolongado, melhor controlaram a situação e a comunicação, tomaram as decisões necessárias mais rapidamente, mostraram autoconfiança e capacidade de exercer influência gerencial e pedagógica, seja responsável.

Palavras-chave: Lyceum educacional; Estilo de gestão da inovação; Modelo de aprendizagem para gestão inovadora do lyceum.

Abstract: The purpose of this article is to present the characteristics, content and logic of the development of an innovative managerial style among the directors of educational lyceums in modern Russia. The study reveals the specific features of this management style, which in general boils down to manager's ability to promote the educational space of the Lyceum to the state of a dynamically developing system that responding to modern requirements for training specialists of innovative economies. As a key criterion for the development of an innovative managerial style, the authors considered the ability of a manager to make a personal contribution to instilling innovation. This criterion made it possible to identify the growth levels of the innovative style of managing the lyceum (reproductive, adaptive, locally-modeling, system-modeling, innovative-creative). The study developed a model for providing innovative managerial activities of the lyceum's director, which is aimed at the formation of constructive leadership potential and a dynamic "Self-concept" of management. The logic of an innovative managerial style formation is revealed, which consists of three stages: the reflective stage, the identification stage, the stage of professional self-actualization. As a result of applying this logic in the research work, the managers of the experimental group developed better tolerance and flexibility of their position, increased creativity, the ability to withstand prolonged psycho-emotional stress, they better control themselves, the situation and communication, faster made the necessary decisions, showed self-confidence and ability exert managerial and pedagogical influence, ability to manage the social situation, bear responsibility.

Keywords: Educational lyceum; Innovative style of management; Model of innovative lyceum management.

Resumen: El propósito de este artículo es presentar las características, el contenido y la lógica del desarrollo de un estilo de gestión innovador entre los directores de los liceos en la Rusia moderna. El estudio revela las características específicas de este estilo de gestión, que se reduce a la capacidad del gerente para promover el espacio educativo del Liceo al estado de un sistema en desarrollo dinámico que cumple con los requisitos modernos para la formación de especialistas en economías innovadoras. Un criterio clave para un estilo de gestión innovador fue la capacidad de un gerente de hacer una contribución personal para inculcar la innovación. Este criterio permitió identificar los niveles de crecimiento del estilo innovador de gestión del liceo (reproductivo, adaptativo, modelado local, modelado de sistemas, innovador-creativo). El estudio desarrolló un modelo de actividad gerencial innovadora del jefe del liceo, que apunta a la formación de un potencial de liderazgo constructivo y un dinámico "auto-concepto" de gestión. Se revela la lógica de la formación de un estilo de gestión innovador, que consta de tres etapas: reflexiva, identificación y la etapa de autorrealización profesional. Como resultado de la aplicación de esta lógica, los gerentes del grupo experimental desarrollaron una mejor tolerancia y flexibilidad del posición, aumentaron su creatividad, su capacidad para resistir el estrés prolongado, se controlaron mejor, la situación y la comunicación, tomaron las decisiones necesarias más rápido, mostraron confianza en sí mismos y capacidad de ejercer influencia gerencial y pedagógica, capacidad de gestionar una situación social, asumir la responsabilidad.

Palabras clave: Liceo educativo; Estilo de gestión innovador; Un modelo para el manejo innovador del Liceo. 


\section{Introduction}

The current period of development of Russian education is under the influence of globalization and informatization processes, which requires updating mechanisms of educational institutions management (SHUTENKO E. et al., 2018). There is a need to move from rigidly administrative managerial methods to democratic-partner, dynamic-reflexive forms of management (RYZHKOVA \& SERGEEV, 2010). This highlights the task of updating the educational process management system, and first, increasing the efficiency of managers' activities, developing their productive and innovative way of thinking and behavior (SERDYUKOV, 2017).

In the humanitarian and scientific dimension, approaches that focus primarily on the study of non-standard behavioral models are of great importance in the study of the effectiveness of innovation management in education (DIMMOCK, 1993). In search of reserves for improving management efficiency, these approaches in various ways go to the analysis of leadership style as a key psychological factor in a management issues as a whole (FAYOL, 1949; IACOCCA \& WHITNEY, 2008).

The beginning of the regular research of leadership style was laid in the middle of the last century under the influence of the well-known experiments of K. Lewin, who identified three main leadership styles: autocratic, democratic and laissez-faire (LEWIN et al., 1939). The findings of these researches have been widely recognized and applied in various fields of science: sociology, psychology, management, pedagogy, and others (SLASTENIN \& PODYMOVA, 1997).

It should be noted that the phenomenon and the genesis of an effective leadership style have long attracted the attention and interest of psychologists and other scientists from various schools and areas. In the existing list of recognized works, well-known researchers point out three scientific traditions:

1) a personal approach that considers the relationship of manager success in connection with his individual traits and characteristics;

2) a behavioral approach that determines the level of effectiveness of the manager according to the patterns of his behavior;

3) a systemic, or situational approach, linking such variables as the peculiarities of the manager, subordinates (the team), and the situation of the activity (task) (MESCON et al., 1985). 
The above classification can also be supplemented by the so-called program-role and multidimensional-functional approaches.

In line with these and other approaches, various criteria are distinguished for the classification of managerial styles: the criterion of participation in management (authoritarian, co-present, autonomous); criterion of managerial functions; the criterion of orientation towards the individual and to the fulfillment of tasks (weak management, task management, club management, middle way management, strong management) (STOGDILL, 1974).

Considering the essence and characteristics of an effective management style, various authors conclude that an attribute of this style is its focus on the continuous development of the organization, which inevitably involves innovation. It should be noted that innovation as an element of management has been studied in science for a long time, very diverse and extensive (DRUCKER, 2007; SALAZAR, 2013).

The established fundamental and applied research in the field of phenomenology and the development of social and managerial innovations allows us to state a number of important statements:

- innovations, expressing the general logic of the correlation of social being and public consciousness, show the need for progressive changes in the development of management activities, such logic is mediated by the situation, sectoral and mental specifics, the type of political structure, etc.;

- the methodological "niche" that innovation fills, as it were, is the dominant type of managerial culture, the latter acts as a substantial beginning in relation to innovations, at different times and in various situations it can generate and retard innovation processes;

- innovations are one of the essential attributes of the management culture, which, as it were, orders innovations, predetermining not only their quality, but also the time of appearance;

- innovations are not fundamentally reduced to specific management actions for implementing reforms;

- innovations are closely connected with the motivation of the subjects of their development and implementation ("innovators", "supporters of innovations", "fluctuating pragmatists", "neutrals", "skeptics", “conservatives");

- the development of a managerial culture means increasing the importance of the personal contribution to innovation;

- among the characteristics inherent in innovations, the following are noted: 
dialectical, phasing, degree of radicalness, ability to serve as a mechanism for the interaction of values and norms, evaluation, riskiness, indicativeness, involvement in status, structuredness, ability to form a strategy of innovative behavior, manageability, social orientation, ability to differentiate people according to their interests, etc. (SERDYUKOV, 2017).

\section{Methodology}

The methodological basis of the study consists of a systems approach based on the search for and finding the integral interrelated characteristics of the pedagogical facts and phenomena being studied; an integrated approach to building methods and methods for studying and transforming the phenomena of reality; principles of unity of consciousness and activity, development, determinism, subjectivity of activity; cultural approach to humanitarian phenomena and processes, personality-axiological approach.

The theoretical bases of the study are:

- teaching about the holistic pedagogical process (SLASTENIN \& PODYMOVA, 1997).

- activity and person-centered approach (LEONTIEV, 1972; ROGERS, 1961).

- an akmeological approach to the empirical study of the phenomenology of the creative development of a professional manager (DERKACH, 2004).

- ideas recognized in the psycho-pedagogical science of the provisions on the role of collective-communicative and creative forms of activity in the formation of socio-cultural skills (PONOMAREV, 1976).

- principles of cultural congruence, integrated support of entry into activity (DIESTERWEG, 1956; KLIMOV, 1998).

To solve the set tasks and verify the initial assumptions, a complex of projectiveempirical methods was used: a method for modeling innovation and management; observational methods (direct, indirect, included observation); diagnostic methods (interview, questioning, testing, ranking method), experimental methods (ascertaining and formative experiments); the study and synthesis of educational experience; the study of educational and methodological documents; mathematical statistical methods of data processing. 


\section{Results}

As the analysis of the educational system of modern Russia has shown, readiness for innovations of directors of educational institutions plays an important role in maintaining its effectiveness (SHUTENKO A. et al., 2018). The current stage of development of secondary special education is characterized by systemic innovations in the field of educational content, pedagogical technologies, in the organization of the educational process and its management, in scientific-pedagogical approaches of advanced qualifications and retraining of teachers, etc. (SHUTENKO E. \& SHUTENKO A., 2015).

\section{Levels of innovative style of management as indicators of lyceum directors'} personal effectiveness. In the present study, innovative management activities were considered as professional, which required the leader to have a sequence of actions, distribution of attention, volitional pressure, overcoming difficulties, unique mental abilities, certain knowledge, skills, and proficiency. The leading regulator of productive management activity, which determines the structure and dynamics of all its other components, considered the logic of actions along the "value $\rightarrow$ motive $\rightarrow$ goal $\rightarrow$ result" line (SALAZAR, 2013).

By effective innovative management of an educational lyceum was meant the ability of a manager to achieve a qualitatively new result of educational activity with the least organizational and resource costs (HOFFMAN \& SPANGEHL, 2011). First of all, this result is the successful employment of graduates in the modern labor market through the fruitful interaction of the educational system with the real sectors of the economy and the market for educational services (SERDYUKOV, 2017).

The personal-activity approach to the study of innovation management has made it possible to establish that the successful managers in the course of their activities form and develop the author's management system of the "Self-concept" of leadership (ROMANOVA, 2020). It is based on the awareness of oneself as a subject of management, capable of transferring the system to a qualitatively new state in the logic of progressive development. Such a leader is convinced that he is endowed with certain powers that require his specific knowledge and skills, namely the ability to organize and establish productive communication with the staff of the educational lyceum at a higher level of professional-teaching activity. Having a "self-concept" of leadership is especially important to ensure an inclusive environment within the integrated learning of students (ROMANOVA et al., 2020). 
The preliminary part of our experimental work was devoted to the study of external and internal factors in the development of innovative management activities.

The contradictions that exist in the practical work of the directors of vocational schools and lyceums of the city of Murmansk and the city of St. Petersburg (Russia) were studied. Analysis of these contradictions showed that the majority of managers $(2 / 3$ of the total number) do not have full compliance between the position held and the necessary skills, experience in communication and management of the educational system. It is no coincidence that many of them tend to follow stereotypical attitudes and patterns of behavior in managerial work that block their willingness to innovate (PODYMOV, 1998).

This fact was reflected in the level of innovative style of management (ISM) among the directors of vocational schools and lyceums, who took part in our study. As a key criterion of the style development, we considered the willingness and ability of the manager to make his personal contribution to the design and implementation of innovations, as well as the value of his efforts (LAMBERT et al., 2002). Thus, the growth levels of the innovative managerial style can be represented in the following gradation:

1) reproductive level means mechanically blind acceptance and application of extraneous innovative experience in their managerial activities;

2) adaptive level implies a certain personal re-processing of ready-made innovations to the tasks of their managerial practice;

3) locally-modeling level means the ability to partially self-made innovations for some tasks and activities of the educational system;

4) system-modeling level - a holistic independent design of innovations for the entire educational system of the Lyceum, with their partial implementation in practice;

5) innovative-creative level - independent design, construction and implementation of innovations in the practice of managing a complete educational system of the Lyceum.

Guided by this scale, we studied the personality and style characteristics of 153 directors of vocational schools and lyceums of Murmansk and St. Petersburg. Figure 1 shows the results of the percentage distribution of directors according to the level of their ISM development.

As shown in the figure 1, most managers had a medium, locally-modeling managerial style $(66 \%)$, a small part was committed to the lowest or adaptive level of management, and none of the directors had the highest, innovative-creative level (see figure 1). 
Figure 1. Distribution of educational lyceum directors by the level of ISM development

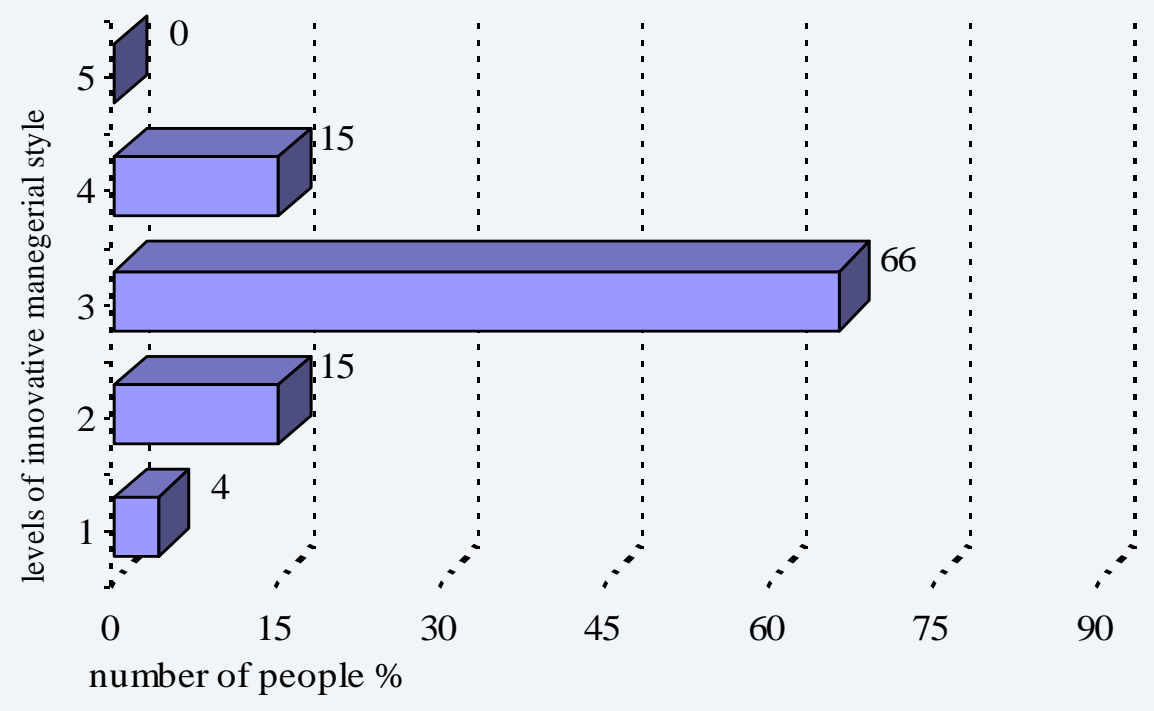

In general, the results obtained are close to the parameters of the normal distribution of statistical data, which indicates the balance and representativeness of the experimental sample.

Further research included a comparative analysis of the managerial styles of lyceum directors with low and high levels of development of the ISM. This analysis was focused on the study of the difficulties experienced by the managers from polar groups through the comparison of the subjective gravities of these difficulties in their daily management work. The calculated results are listed in table 1.

As the data showed, directors with low ISM experience the most serious difficulties in solving such problems as: understanding the importance of teachers' self-development and the need to improve their qualifications in the new economic environment, as well as the willingness to train employees with new professional-pedagogical technologies. At the same time, the ability to clearly set the tasks of the lyceum in changing economic conditions apparently does not cause serious difficulties for them (see table 1).

In contrast to this category, for directors with a high level of ISM, the ability to train subordinates with new professional and pedagogical technologies is not a serious problem. In addition, they are also easily able to solve current problems of the lyceum's activities quickly and able to rally and inspire a team of like-minded colleagues. As for their problems, they experience the greatest difficulties with the ability to control themselves, namely their time, emotions, health and professional development (see table 1). 
Table 1 - Comparative estimates of difficulties in the activities of directors with high and low levels of ISM

No

Content of difficulties
Degree of difficulty (in points, $\max =6$ ) directors with directors with low ISM high ISM

1 Awareness of the importance of teachers' selfdevelopment and the need to update their 5,85 2,50 qualifications in the new economic environment

2 Ability to train colleagues in new professional5,70 2,00 pedagogical technologies

3 The ability to solve the current problems of the activities of the educational lyceum quickly

4 Creative management, self-management 5,25

5 Ability to gather a group of like-minded 5,00 2,10 professionals

6 The ability to protect teachers and students from social and financial difficulties

7 The ability to independently determine the immediate prospects for the Lyceum development

8 The ability to manage yourself: emotions, time, 4,60 health, professional growth

9 Understanding the essence of the director's role and responsibility

10 Understanding the specifics of managing an educational Lyceum in the new economic circumstances

11 The ability to clearly define the tasks of the lyceum in a changing economic environment.

Obviously, complete immersion in work and excessive employment do not allow directors with a high level of ISM to pay much attention to themselves, although the degree of subjective difficulty of this problem is not so great (3.35 points out of 6 maximum).

On the whole, it is necessary to note an increased subjective background of difficulties in working with managers with low ISM who are harder to cope with their managerial tasks; they are often fixated on current problems and do not consider colleagues as a pillar and resource for solving managerial tasks. 
Deployment model of innovative lyceum management. Based on the conducted research, it was established that the innovative managerial activity of the director for managing the educational system "educational lyceum" depends on the level of managerial and pedagogical skills and the formed individual system of "Self-concept" leadership.

Figure 2. Model for providing innovative managerial activities of the lyceum's director

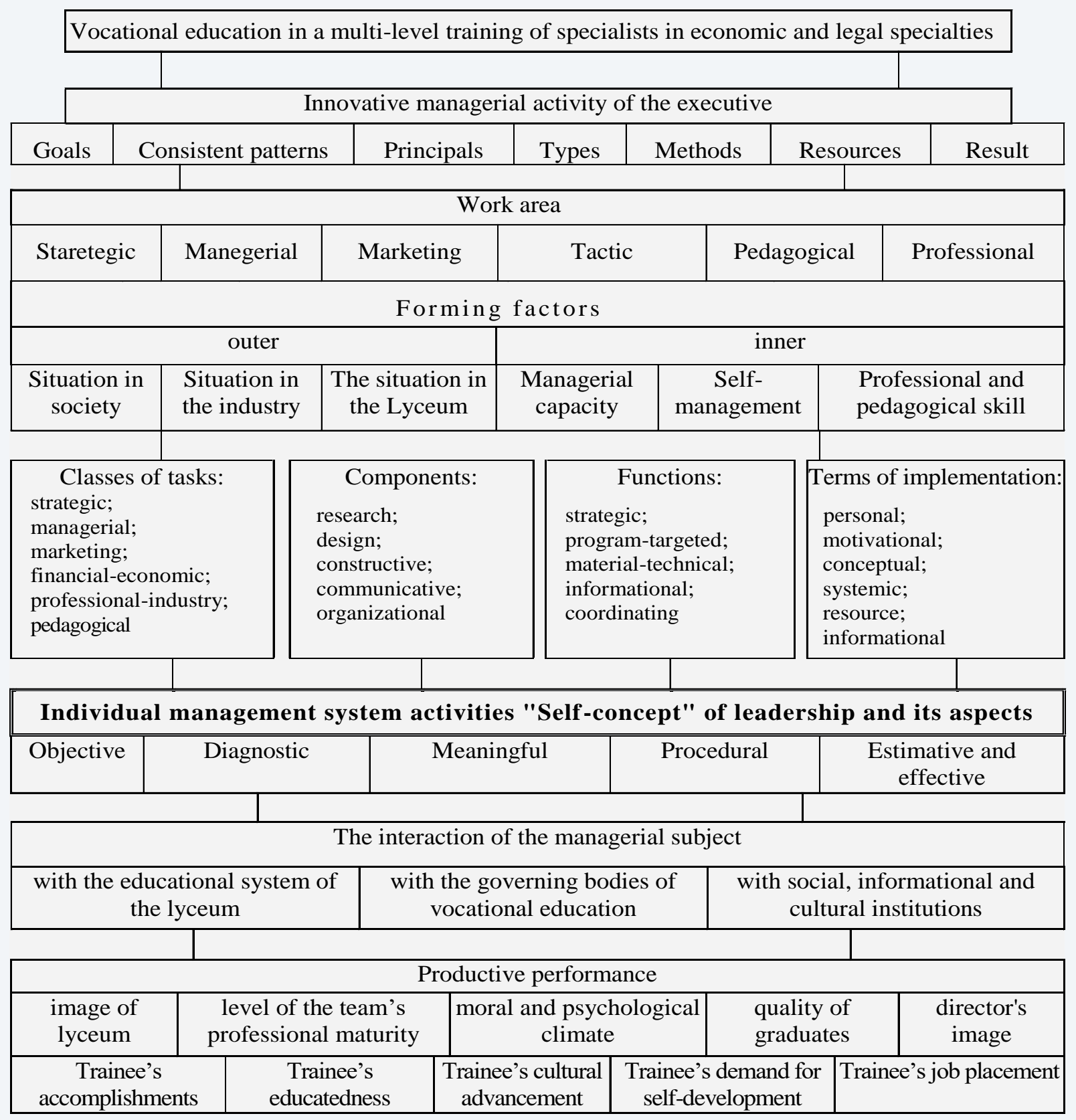

The study revealed that lyceum heads with strategic managerial potential have a detailed comprehension of the development goals of their lyceum and can modeled the conditions for their achievement. They can clearly articulate the goal and consistently develop a strategy for its implementation. They also possess a strategic concept, they own the 
management technologies, are capable to carry out the basic functions of lyceum management, can assemble team of like-minded people. Ultimately, they are aimed at developing a "creative field" for generating innovative activities. Advanced strategic skills, reflective control, a systematic of managerial-pedagogical consulting for fellow teachers on modern educational technologies are significant aspects of the ISM.

At the projective stage of our study, we developed a model of innovative managerial activities of the director of the Lyceum, which is shown schematically in Figure 2.

As shown in the figure 2, the distinctive particularities of productive innovative lyceum management are:

- four-component management (strategic, tactical, operational, self-government);

- a change in the development-oriented management algorithm;

- restructuring the content of the management functions (program-targeted, research-prognostic, as well as the coordinating focus of functions of the organization, planning, management, control);

- changing the place and role of the director in the management system of an educational lyceum (the principal strategist, inspector and methodologist in his lyceum is the director);

- management of the educational organization based on the feedback principle, which provides the objective level of control over the actual results, allowing the director to compare the desired results with the real state of things, and thereby effectively perform managerial functions;

- $\quad$ systematic, multifactorial, predictive, self-reproducible construct of management.

In the presented model, the results of the activity of the educational system are correlated with the results of the activity of the director, which depend on the formation of the factors of the innovation management activity.

The principal points and provisions of presented model formed the basis for development a formative experiment, which was spend among the described groups of lyceum managers as part of refresher courses.

The logic of ISM development among directors of educational lyceums. The formative experiment of our research work was generally focused at stimulating the motivational-value attitude of managers towards to innovation activities as an chance for selfrealization and rising the efficiency of their managerial work. 
The whole complex of experimental work was carried out in the logic of three successive stages: the reflexive stage, the identification stage and phase of professional selfrealization.

The first reflective stage was aimed at understanding the creative potentialand overcoming erroneous stereotypes (PODYMOV, 1998). The work consisted of a comprehensive diagnosis of the actual professional image of the manager and his personal characteristics. The methodical support was tests for identifying the optimism and activity of the manager personality, flexibility of thinking, strategies and models of overcoming behavior, the level of need achievement, personal orientation, psychological readiness for risk, tests for a communicative optimum, job satisfaction. Self-description and self-reporting methods were also used. (SHUTENKO, 2015).

Work developed in an individual form. Particular attention was paid to the study and detection of various distorting stereotypes such as:

- filtering (the director selects negative moments and manipulates them, filtering all the positive aspects of the situation);

- polarized thinking (all things seem either black or white; either bad or good, there are no other options);

- over-generalization (a manager seeks a generalized solution based on a single incident, if something bad happens, he expects it to be over and over again);

- "expert on people" (not accepting all the facts, the manager judges people and "knows" why they behave this way and not otherwise);

- personalization (the manager's conviction that the thoughts, intentions and actions of people around him is nothing more than a reaction to his own person);

- mistakes of justice (the director feels indignation, because he thinks he knows what is fair, but other people disagree with him);

- censure (the leader considers other people to be responsible for current difficulties difficulties and blames them or censures himself for each problem);

- obligation (the manager has a set of rules prescribing how he and other people should act, people who violate the rules threaten him, and he himself feels guilty if he deviates from the rules);

- emotional understanding (the leader automatically believes that his feelings are unmistakable); 
- errors of change (the manager expects others to change in accordance with his requirements, if he exerts enough pressure or sufficiently feels them).

- global level (a manager on the basis of one or two qualities makes a negative judgment);

- "to be right" (the leader is sure that his opinion or actions is correct, and the possibility of error is not comprehended);

- remuneration mistakes (the manager expects that all his sacrifices and self-denial will be rewarded and feel bitterness when this does not happen).

The second stage, the identification was carried out in the form of group classes and was aimed at the adoption by the director of his real "Self" in the emerging managerial activity and awareness internal potentials of self-development in the context of innovative educational activity (JERSILD, 1955). The content of this stage were exercises and free discussions, improvisational games, games-dramatization, psychological trainings aimed at integrating the professional "Self concept", increasing competence in managerial interaction (GUILE \& GRIFFITHS, 2001).

The methodical support was provided by the exercises: "sculptural composition" of an ideal and real leader, psycho-gymnastic exercises for the development of observation, understanding the states, properties, qualities and attitudes of people and groups, increasing and restoring work, developing creativity, increasing self-confidence, improving communication skills (establishing contact, overcoming communication barriers, listening skills, etc.).

The third stage acted as a stage of professional self-realization. It was aimed at releasing internal potential and encouraging managers to choose an innovative mode of activity as a subjectively significant form of self-realization in managing the lyceum. (MASLOW, 1987).

At this stage, the following forms of work were used: consultations, seminars and group practical exercises, pedagogical council. Methods of support: methods of consulting work, training and correction techniques, solving pedagogical situations, methods of pedagogical and transactional analysis, "behavioural rehearsal", indirect feedback, verbalization of internal dialogue, "professional mirror", designing and cultural restoration of values, mini- conferences, game re-enactment of managerial experience situations, protection of plans and innovations, problematic discussions, professional advice, filling out a diary of self-awareness, brainstorming. 
Monitoring of effectiveness of the experimental work. For the control and final measurements, we used the classical method of E. Shostrom, called the Personal Orientation Inventory (POI). To assess the effect of experimental work, indicators of innovative leadership style to be measured were formulated: temporal identity, self support, value harmony, flexibility of behaviour, self-regard, self-acceptance, positive faith in humanity, synergy, tolerance, responsiveness and openness, cognitive interest, creativity (SHOSTROM, 1974).

Measurement data showed that as a result of the experimental work carried out, the leaders of the experimental group showed greater tolerance and flexibility of their position, increased creativity, the ability to withstand prolonged psycho-emotional stress without a significant reduction in the productivity of activities, they better control themselves and the situation, communication, faster make the necessary decisions, demonstrate greater confidence in themselves and their ability to provide managerial and pedagogical influence, show the big ability to manage a social situation, to bear responsibility. Table 2 . reflects the data of comparative measurements of such criterial qualities.

Table 2 - Comparative measurement data of the self-actualization test (POI,

Shostrom) in the control group (CG) and experimental group (EG)

\begin{tabular}{|c|c|c|c|c|c|}
\hline \multirow{2}{*}{ No } & \multirow{2}{*}{ Indicators } & \multicolumn{2}{|c|}{ before the experiment } & \multicolumn{2}{|c|}{ after the experiment } \\
\hline & & CG & EG & CG & EG \\
\hline 1. & temporal identity & 6,3 & 5,9 & 6,6 & 6,4 \\
\hline 2. & self support & 4,9 & 5,3 & 4,2 & 6,6 \\
\hline 3. & value harmony & 5,2 & 5,8 & 5,0 & 7,2 \\
\hline 4. & flexibility of behaviour & 4,7 & 4,5 & 4,9 & 6,4 \\
\hline 5. & self-respect & 6,7 & 7,1 & 6,9 & 7,4 \\
\hline 6. & self-acceptance & 7,1 & 6,4 & 7,3 & 7,0 \\
\hline 7. & positive faith in humanity & 6,3 & 6,7 & 5,9 & 7,3 \\
\hline 8. & synergy & 4,6 & 5,0 & 4,8 & 6,3 \\
\hline 9. & tolerance & 6,2 & 5,3 & 5,7 & 7,1 \\
\hline 10. & responsiveness and openness & 6,6 & 6,4 & 5,9 & 7,9 \\
\hline 11. & cognitive interest & 5,9 & 5,8 & 6,3 & 6,7 \\
\hline 12. & creativity & 7,4 & 6,9 & 7,6 & 8,2 \\
\hline
\end{tabular}




\section{Discussion}

The results obtained generally show the positive effect of the experimental work done.

The results of the monitoring of experimental work indicate a distinct pedagogical effect of the study, and the identified and reasonable pedagogical conditions are sufficiently effective for the formation of an innovative style of management in an educational lyceum.

The effectiveness of the developed model is confirmed by the positive results of educational lyceums management by the directors of the experimental group:

- the quality of preparation of lyceum graduates has improved, their "image" in the educational services market has changed for the better ( $92 \%$ graduates enrol in universities);

- the moral-psychological climate in the collectives has improved;

- the layer of professionalism and professional-pedagogical competence of teaching staff has grown;

- increased orientation of all participants of the educational process to achieve the desired result of managerial activity;

- the sphere of social protection of teachers and students in lyceums was developed.

\section{Conclusions}

An innovative style of lyceum management is a professional and essential trait of the personality of a leader, reflecting his capacities and resource to form an innovative environment in the educational space of the lyceum. This environment is based on a positive moral and psychological climate, supported by a set of managerial and pedagogical measures aimed at introducing progressive innovations in the educational process.

The formation of an innovative managerial style in an educational lyceum essentially depends on the constructive orientation of the leader's personality, his "Self-concept" of management in the logic of the dynamic growth of the lyceum system. The following significant relationships are identified:

- between the stylistic features of managerial activity, on the one hand, and the attitudes in the manager's consciousness structure (which form the basis of his managerial position, subjective model of management, an implicit theory of the personality of the teacher and student), on the other hand; 
- between the subjective model of effective management and the sphere of management, which has a significant impact on the change in the managerial position of the manager, his understanding of the goals and objectives of management;

- between the individual psychological characteristics of the personality of the leader and the subjective picture of management activities, attitudes and stereotypes in the perception of managerial and pedagogical situations, the actual style of management implemented by the leader.

The logic of the development of an innovative managerial style is described by the following stages:

- reflexive stage - comprehension of the real professional-managerial image and understanding of one's creative potential;

- identification stage - the adoption by the director of his real "Self" in the emerging management activities, awareness of the personal resources of self-development in the perspective of innovation;

- stage of professional self-actualization - the emancipation of internal potential and the implementation of the choice of the method of innovation as a subjectively significant form of self-realization in management activities.

\section{REFERENCES}

DERKACH, A.A. (2004). Akmeologic basis of development of professionalism. MoscowVoronezh. 750 p.

DIMMOCK, C. (Ed.) (1993). School-based management and school effectiveness. Abingdon: Routledge.

DIESTERWEG, A. (1956). Selected pedagogical essays. Moscow: Uchpedgiz. 374 p.

DRUCKER, P. (2007). Innovation and Entrepreneurship: Practice and Principles. Butterworth-Heinemann.

GUILE, D. \& GRIFFITHS, T. (2001). Learning through work experience. Journal of Education and Work, 14(1), 113-131.

FAYOL, H. (1949). General and Industrial Management. Translated by C. Storrs, Sir Isaac Pitman \& Sons, London. 
HOFFMAN, A. \& SPANGEHL, S. (Eds). (2011). Innovation in Higher Education: Igniting the Spark for Success. American Council on Education, Rowman \& Little field Publishers Inc., Lanham, MD.

IACOCCA, L. \& WHITNEY, C. (2008). Where Have All the Leaders Gone? New York/ London/ Toronto/ Sydney: Scribner.

JERSILD, A.T. (1955). When teachers face themselves. Oxford, England: Bureau of Publications, Teachers Co.

KLIMOV, E.A. (1998). Introduction to the psychology of labor: Introduction to the psychology of labor: a textbook for high schools. Moscow: Culture and Sports: UNITI. 343p.

LAMBERT, L., WALKER, D., ZIMMERMAN, D. P., COOPER, J. E., LAMBERT, M. D., GARDNER, M. E., \& SZABO, M. (2002). The constructivist leader (2nd ed.). New York: Teachers College, Columbia University.

LEWIN, K., LIPPIT, R. \& WHITE, R.K. (1939). Patterns of aggressive behavior in experimentally created social climates. Journal of Social Psychology, 10, 271-301.

MASLOW, A. (1987). Motivation and Personality. N.Y: Addison-Wesley.

MESCON, M.H., ALBERT, M. \& KHEDOURI, F. (1985). Management. New York: Harper and Row, Publishers.

PODYMOV, N.A. (1998). Psychological barriers in teaching. Moscow: Prometheus, 239 p.

PONOMAREV, Ya.A. (1976). Creativity psychology and pedagogy. Moscow: Pedagogy. $280 \mathrm{p}$.

ROGERS, C.R. (1961). On becoming a person. Boston, MA: Houghton Mifflin.

ROMANOVA, G. (2020). The Readiness of Leading and Teaching Staff to Develop Students' Sociocultural Competence in the Inclusive Learning Environment. Pedagogika, 138(2), 226-243. https://doi.org/10.15823/p.2020.138.13

ROMANOVA, G. A., ANANISHNEV, V. M. \& DARDA, E. S. (2020). Inclusive education: A path to equal rights. Opcion, 36 (Special Edition 26), 613-628.

RYZHKOVA, I.V. \& SERGEEV, A.M. (2010). Specific Features of internationalization of higher education in the framework of the northern dimension. Baltic Region, 3, 24-37.

SALAZAR, P. (2013). High-impact leadership for high- impact school: The actions that matter most. New York, NY: Routledge.

SERDYUKOV, P. (2017). Innovation in education: what works, what doesn't, and what to do about it? Journal of Research in Innovative Teaching \& Learning, 10 (1), 4-33.

https://doi.org/10.1108/JRIT-10-2016-0007 
SHOSTROM, E.L. (1974). Manual for the Personal Orientation Inventory. San Diego, California: EdITS/Educational and Industrial Testing Service.

SHUTENKO, A.I., SHUTENKO, E.N., SERGEEV, A.M., RYZHKOVA, I.V., KORENEVA, A.V. \& TEGALEVA, T.D. (2018). Socio-cultural Dominants of Higher School Innovation Mission. Espacios, 39(52), 34. https://www.revistaespacios.com/a18v39n52/18395234.html

SHUTENKO, E.N. (2015). Motivational and Conceptual Aspects of Student Self-fulfillment in University Education. Procedia - Social and Behavioral Sciences, 214(5), 325-331. http://www.sciencedirect.com/science/article/pii/S1877042815060073.

SHUTENKO, E.N. \& SHUTENKO, A.I. (2015). Socio-Cultural Trends in the Development of the Higher School's Innovative Potential. Procedia - Social and Behavioral Sciences. 214(5), 332-337. http://www.sciencedirect.com/science/article/pii/S1877042815060103

SHUTENKO, A.I, SHUTENKO, E.N, SERGEEV, A.M., RYZHKOVA, I.V., TALYSHEVA, I.A. \& TSAREVA, E.V. (2018). The use of modern ICT to provide students' self-realization in Russian higher school. Espacios, 39(43), 15.

http://www.revistaespacios.com/a18v39n43/18394315.html

SLASTENIN, V.A. \& PODYMOVA, L.S. (1997). Pedagogy: innovative activity. Moscow: Magister. 224 p.

STOGDILL, R. M. (1974). Handbook of leadership: A survey of the literature. New York: Free Press.

\section{ABOUT THE AUTHORS:}

\section{Andrey I. Shutenko}

Ph.D. of Pedagogy, Senior Scientific Fellow, Institute of Economics and Management, Belgorod State Technological University named after V.G. Shukhov, Belgorod, Russia. Email: avalonbel@mail.ru

https://orcid.org/0000-0002-8385-3660

\section{Anastasia V. Koreneva}

Doctor of Pedagogy, Professor, Department of Philology and Media Communications, Murmansk Arctic State University, Murmansk, Russia. E-mail: korenevaanast@mail.ru https://orcid.org/0000-0002-4901-4927

\section{Inna V. Ryzhkova}

Ph.D. of Pedagogy, Head of Scientific Work and International Cooperation Department, Murmansk Arctic State University, Murmansk, Russia. E-mail: innaryzhkova@yandex.ru https://orcid.org/0000-0003-3372-020X 


\section{Larisa P. Morina}

Doctor of Philosophy, Professor, Department of Cultural Studies, Philosophy of Culture and Aesthetics, St. Petersburg State University. St. Petersburg, Russia. E-mail:

spb.lmp@gmail.com

(iD) https://orcid.org/0000-0002-3905-1265

\section{Alexander V. Apykhtin}

Ph.D. Philosophy, Senior lecturer, Department of Cultural Studies, Philosophy of Culture and Aesthetics, St. Petersburg State University, St. Petersburg, Russia E-mail:

sashatin44@gmail.com

https://orcid.org/0000-0001-6242-3533

\section{Galina A. Romanova}

Ph.D. of Pedagogy, Associate Professor, Department of educational systems, Academy of Public Administration, Moscow Region, Russia. E-mail: galinaromanova3@ rambler.ru

https://orcid.org/0000-0002-3017-8999

Recebido em: 6 de junho de 2020 Aprovado em: 17 de novembro de 2020 Publicado em: 01 de dezembro de 2020 